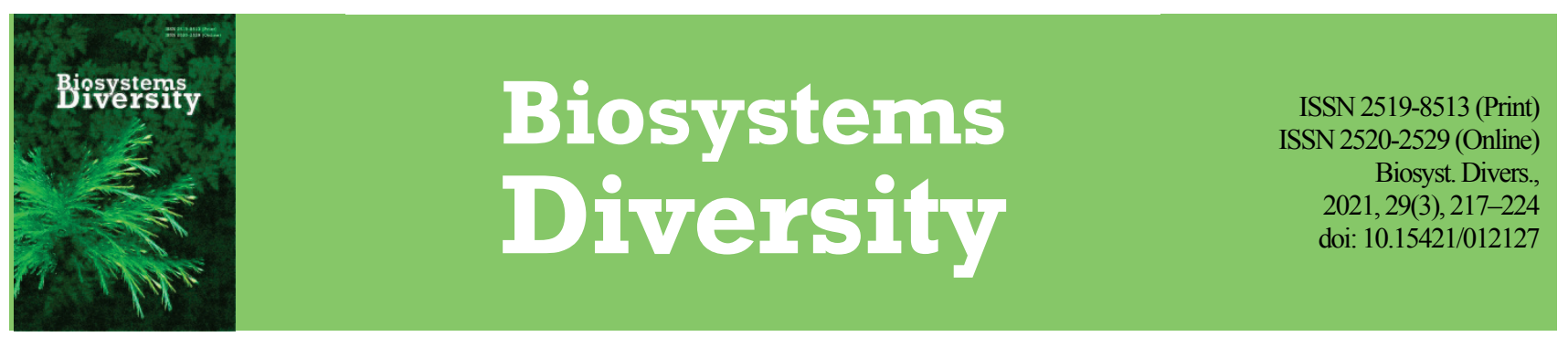

\title{
Changes in the structure and dominance of the zooplankton community of the Kremenchuk Reservoir under the effect of climate changes
}

\author{
S. V. Kruzhylina*, I. Y. Buzevych*, N. Y. Rudyk-Leuska**, M. I. Khyzhniak**, A. V. Didenko* \\ *Institute of Fisheries of the National Academy of Agrarian Sciences of Ukraine, Kyiv, Ukraine \\ **National University of Life and Environmental Sciences of Ukraine, Kyiv, Ukraine
}

Article info

Received 10.06.2021

Received in revised form 07.07.2021

Accepted 08.07.2021

Institute of Fisheries

of the National Academy

of Agrarian Sciences

of Ukraine, Obukhivska st.,

135, Kyiv, 03164, Ukraine.

Tel.: +38-099-359-60-77.

E-mail:sveta_kru@ukr.net

National University of Life and Environmental Sciences

of Ukraine, General

Rodimtsevst. 19

Kyiv, 03041, Ukraine

Tel.: +38-067-274-09-17.

E-mail:

rudyk-leuska@ukr.net

\begin{abstract}
Kruzhylina, S. V., Buzevych, I. Y., Rudyk-Leuska, N. Y., Khyzhniak, M. I., \& Didenko, A. V. (2021). Changes in the structure and dominance of the zooplankton community of the Kremenchuk Reservoir under the effect of climate changes. Biosystems Diversity, 29(3), 217-224. doi:10.15421/012127
\end{abstract}

Zooplankton plays an important role in aquatic food webs and changes in its abundance and diversity under changing climatic conditions can significantly affect the abundance and diversity of other aquatic organisms. The aim of the study was to assess quantitative and qualitative parameters of zooplankton development, dynamics of development of its dominant groups and the effect of water temperature. Species composition and abundance of zooplankton of the Kremenchuk Reservoir were studied in 2006, 2010-2012 and 2020 in relation to water temperature and pollution. Zooplankton species diversity fluctuated significantly over the years of the study. A total of 46 taxa were recorded in the reservoir during the study period. The number of recorded zooplankton taxa ranged 26 to 32 depending on the year. The most abundant zooplankters were Chydorus sphaericus, Copepoda nauplii, Brachionus diversicornis. The abundance of zooplankters in the reservoir during the study period ranged $23 \cdot 10^{3}$ to $256 \cdot 10^{3}$ ind. $/ \mathrm{m}^{3}$, and biomass 0.14 to $0.89 \mathrm{~g} / \mathrm{m}^{3}$. A significant positive relationship was observed between the abundance of cladocerans, including some individual species (Ch. sphaericus and Ceriodaphnia sp.), and water temperature. Indicator species of water pollution in different years and in different parts of the Kremenchuk Reservoir differed significantly, which probably depended on the presence or absence (in a certain period of time) of polluting discharges. The total saprobity index in different years in different parts of the reservoir was in the range of 1.5-1.9. Structural indicators of zooplankton and its dominant complexes characterize the water in the Kremenchuk Reservoir as $\beta$-mesosaprobic. It is probably too early to assess the impact of climate change zooplankton as these changes are still unstable and short in time, but it is necessary to constantly monitor the biota of aquatic ecosystems to further study and summarize the data, which could later allow an identification of such changes.

Keywords: water temperature; Dnieper River; abundance; biomass; saprobity; copepods; cladocerans.

\section{Introduction}

The Dnipro reservoirs are a unique man-made objects, the ecological state of which develops under the impact of a complex of factors of external and internal origin. Due to the significant ecological and economic importance of reservoirs, the response of their ecosystems to this impact should be the subject of monitoring studies, which would include both assessment of integrated biocoenotic parameters and determination of individual groups of aquatic organisms, which, in particular, can define the direction and intensity of the succession status of a water body. In this aspect, zooplankton is of great interest. This group of organisms, which in reservoirs occupy mainly niches of first- or second-order consumers, is a critical component of food supply for fish juveniles and one of the main links in water self-purification (Yermolaeva, 2008). Accordingly, without having a holistic picture of the state of zooplankton and the factors that affect it, it impossible to understand the mechanisms of the impact of external factors on the biodiversity, ecological sustainability and bioresource potential of aquatic ecosystems.

Studies of climate change have become especially important in recent years as a powerful factor affecting the conditions of both individual species and biocenoses as a whole. This fully applies to aquatic organisms, habitats of which are more stable (compared to terrestrial ecosystems), but the variability of global climate indices has effects on the production and degradation processes in aquatic ecosystems. In particular, an increase in air temperature causes increased atmospheric circulation and intensification of the rise of nutrients in the upper layers of water. In turn, this results in enhanced photosynthesis as a basis for the formation of a higher trophic status of the aquatic ecosystem and increase in fish productivity (Sokolov,
2010). The main responses of freshwater zooplankton to climatic influences are considered to be changes in the abundance, distribution and structure of zooplankton communities (Vadadi-Fulop et al., 2012). Changes in zooplankton abundances in response to rising average temperatures were shown for some reservoirs and lakes (Jeziorski et al., 2016; Korneva et al., 2019); however, in other lentic systems, the dynamics of zooplankton abundances in the context of climate change did not show clear trends (Carter \& Schindler, 2012; Fomina \& Syarki, 2018). In this regard, there is a question about the impact of these changes on the structural and functional parameters of main groups of aquatic organisms as a component of the study of patterns of transformation of aquatic ecosystems in conditions of regulated river flow and multi-vector impact of external factors (Romanenko et al., 2019).

In addition, human impact remains a significant factor that affects aquatic bioresources. For example, intensive anthropogenic pressure reduces the intensity of development of zooplankton groups and results in a change of oligo- and polydominant groups to monodominant ones and instability of average annual values with a general tendency to a decrease (Zimbalevskaya, 1989; Pashkova, 2003; Kruzhylina \& Didenko, 2007; Pashkova, 2010).

In general, ecosystems of reservoirs are under the continued effect of a complex of external factors, some components of which are characterized by instability and multi-vector nature (Zimbalevskaya et al., 1987; Shcherbak et al., 1991; Shcherbak \& Yemel'yanov, 2002). Accordingly, data showing the state of aquatic organisms are sufficient to develop an optimal scheme of rational water use with the level of objectivity, which can be obtained only in the framework of the implementation of a continued monitoring system. Thus, in conditions of continued changes in both 
the hydrological regime of the reservoirs and human impact on its ecosystem, there is a need for assessing the dynamics of macroindicators of communities, which form a significant segment of flows of matter and energy in aquatic ecosystems.

\section{Material and method}

Material for the study was collected on a boat throughout the entire area of the Kremenchuk Reservoir in August of 2006, 2010-2013 and 2020 using a permanent network of sampling stations (30 points). Zooplankton was collected by a conical Judy net (opening diameter $25 \mathrm{~cm}$, mesh size $125 \mu \mathrm{m}$ ) by vertically hauling it from the bottom to the water surface. Collected zooplankton samples were placed in $100 \mathrm{ml}$ glass bottles and preserved in a 4\% formaldehyde solution for further laboratory processing. Water temperature at the sampling sites was measured using an electronic thermometer.

In the laboratory, invertebrates from zooplankton samples were identified to the lowest possible level and counted under a microscope ( $x 40$ $100)$ in a counting chamber. Zooplankton abundance data were expressed in density (ind. $/ \mathrm{m}^{3}$ ). Individual weights of organisms were estimated using published length-weight regression relationships (Mordukhai-Boltovskoi, 1954; McCauley, 1984; Watkins et al., 2011). Zooplankton biomasses were expressed as $\mathrm{g} / \mathrm{m}^{3}$.

Saprobity values for individual species were taken from tables of saprobity indices (Gubacek, 1977). Saprobity indices were calculated using the Pantle and Buck method according to Sládeček (1985).

Zooplankton abundances, biomasses and saprobity were analyzed for the total area and separately for three parts of the Kremenchuk Reservoir: upper, middle, and lower, where the upper part is a lotic shallow reach, which extends from Kaniv to railway bridge near Cherkasy; the middle part is a limnetic reach with an average depth of about $2 \mathrm{~m}$, which extends from the railway bridge to the line Adamivka-Zhovnyno; the lower part is a limnetic reach with an average depth of about $10 \mathrm{~m}$, which extends from the line Adamivka-Zhovnyno to the dam of the Kremenchuk Hydroelectric Power Plant.

Classification by Rogozin et al. (2015) was used to separate zooplankters in relation to the temperature: cryophiles (indicator weight $0.75<\mathrm{t} \leq 1.50)$, thermophiles $(1.50<\mathrm{t} \leq 2.25)$ and thermobionts $(\mathrm{t}>$ 2.25 ). Linear regressions were used to determine the relationship between abundances of most abundant groups of zooplankters and water temperature. One-way ANOVA with post-hoc Tukey-Kramer test was used to compare mean abundances of copepods, cladocerans, and rotifers in different years. The normality of data distribution was assessed using the Kolmogorov-Smirnov test. Abundances of zooplanktonic organisms were log-transformed to meet the assumptions of normality. Continuous variables were presented as means and standard errors $(\mathrm{x} \pm \mathrm{SE})$. Calculations and statistical processing of data was conducted in JMP IN 10 (SAS Institute).

\section{Results}

During the studied period, significant year-to-year fluctuations of zooplankton abundances and biomasses in the Kremenchuk Reservoir were observed, the total abundances varying $23 \cdot 10^{3}$ to $256 \cdot 10^{3}$ ind. $/ \mathrm{m}^{3}$ and biomasses 0.14 to $2.11 \mathrm{~g} / \mathrm{m}^{3}$ (Figs. 1 and 2). In the analyzed samples, most important zooplankters by abundance and biomass throughout almost all years were cladocerans, except in 2020 , when a change of dominant groups was observed and rotifers became most abundant. The least pronounced year-to-year fluctuations were recorded for copepods (CV was $38.9 \%$ for the abundance and $64.4 \%$ for biomass). No significant trends were detected between the abundances and biomasses of copepods and rotifers and water temperature during the study period (Fig. 1 and 2).

No significant differences were found among mean abundances of copepods (ANOVA: $\mathrm{F}_{5,55}=1.85, \mathrm{P}=0.118$ ), cladocerans (ANOVA: $\mathrm{F}_{5,55}=$ $1.62, \mathrm{P}=0.170)$ in different year. However, mean abundances of rotifers significantly varied in different years (ANOVA: $\mathrm{F}_{5,55}=5.09, \mathrm{P}<0.001$ ), where significant differences were observed between 2010 and other years except 2006 (Tukey-Kramer test, P < 0.05). Overall, 2010 was characterized by lowest abundance of rotifers in the Kremenchuk Reservoir during the study period.

A significant relationship was observed between the abundance of cladocerans (log-transformed data) and water temperature (linear model: $\mathrm{P}=0.035$, Fig. 3). No significant relationship was found for zooplankton biomass.

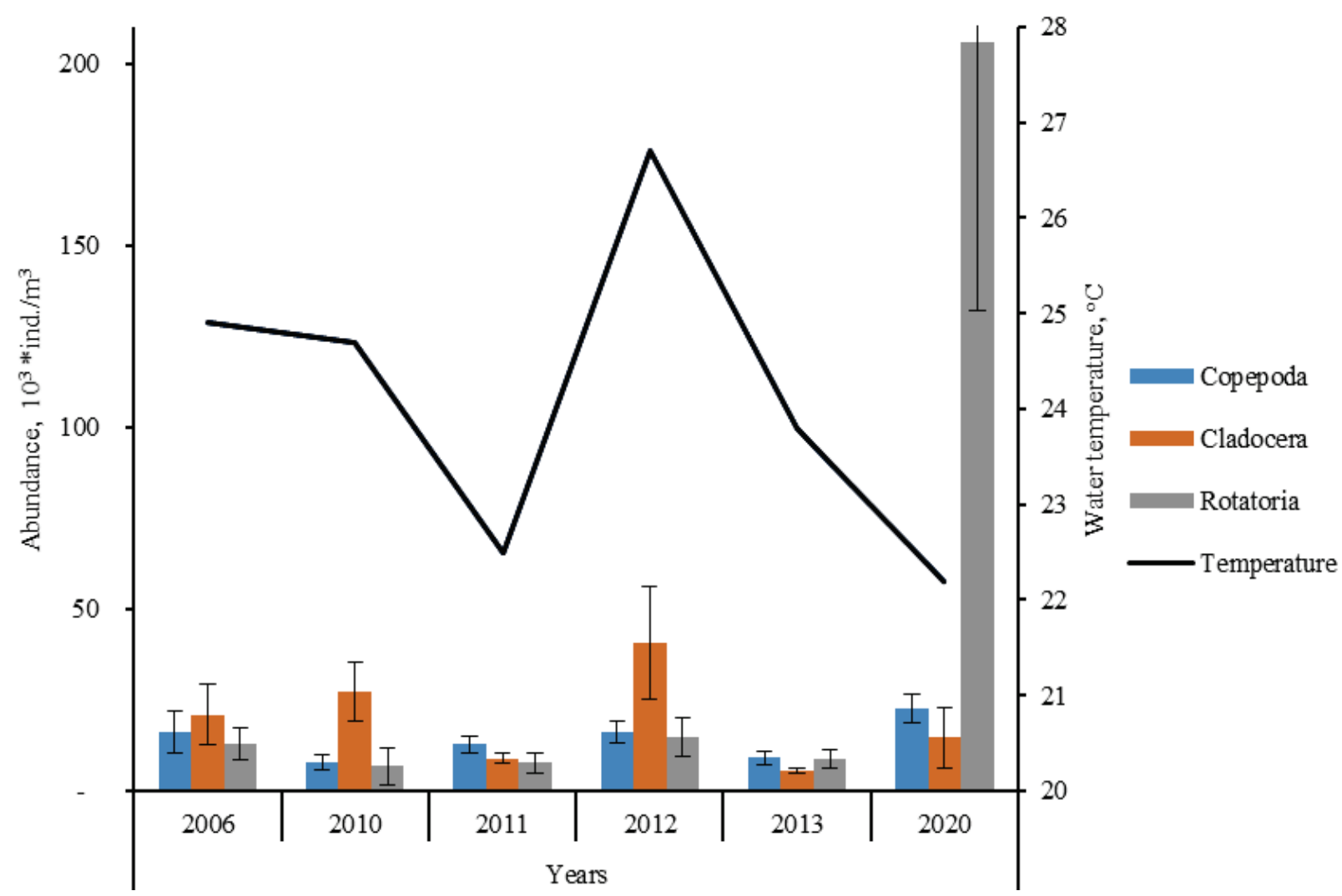

Fig. 1. Year-to-year dynamics of the abundance of zooplankton organisms $(\mathrm{x} \pm \mathrm{SE})$ and water temperature in the Kremenchuk Reservoir by years 


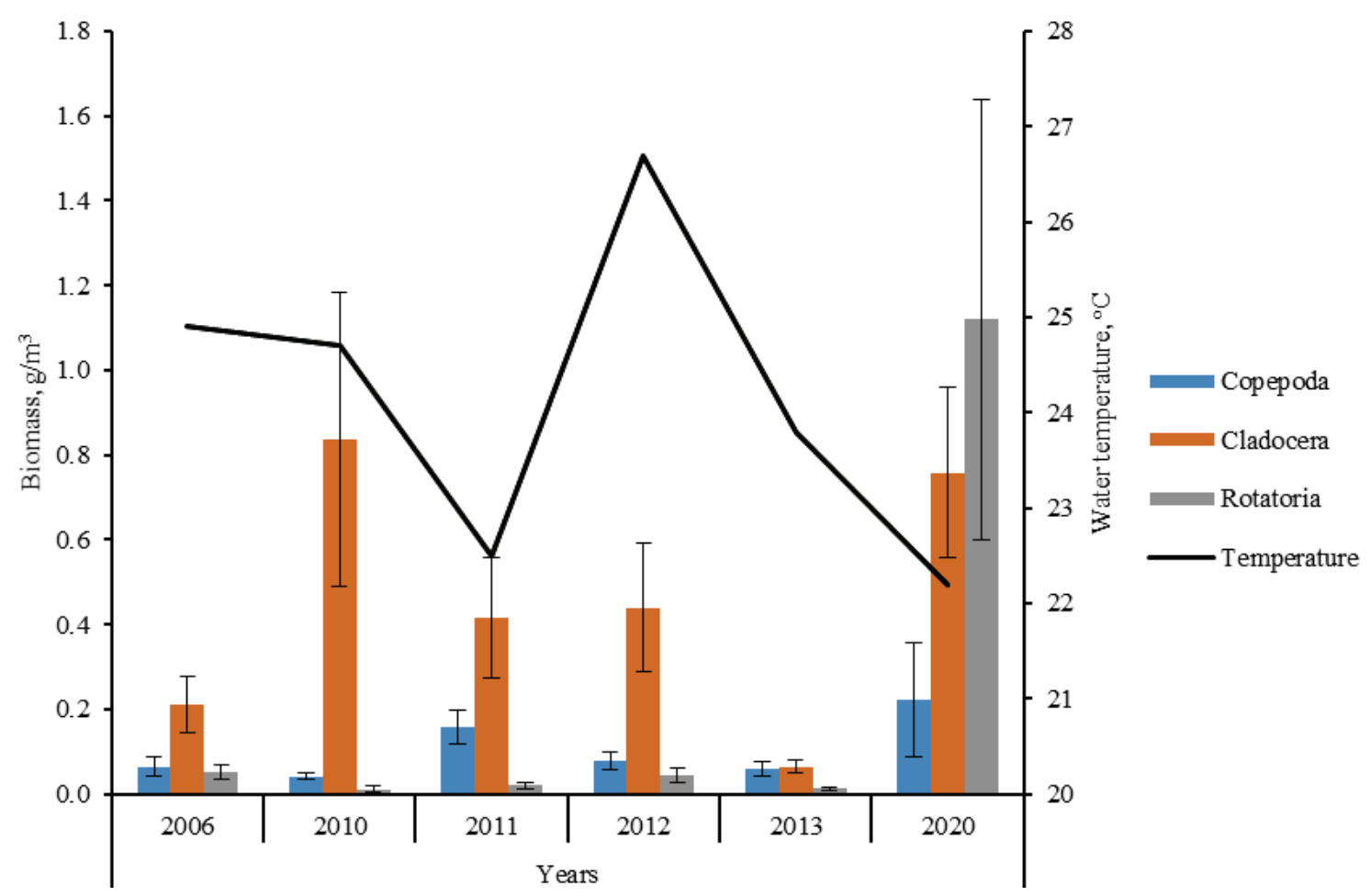

Fig. 2. Year-to-year dynamics of the biomass of zooplankton organisms $(x \pm S E)$ and water temperature in the Kremenchuk Reservoir

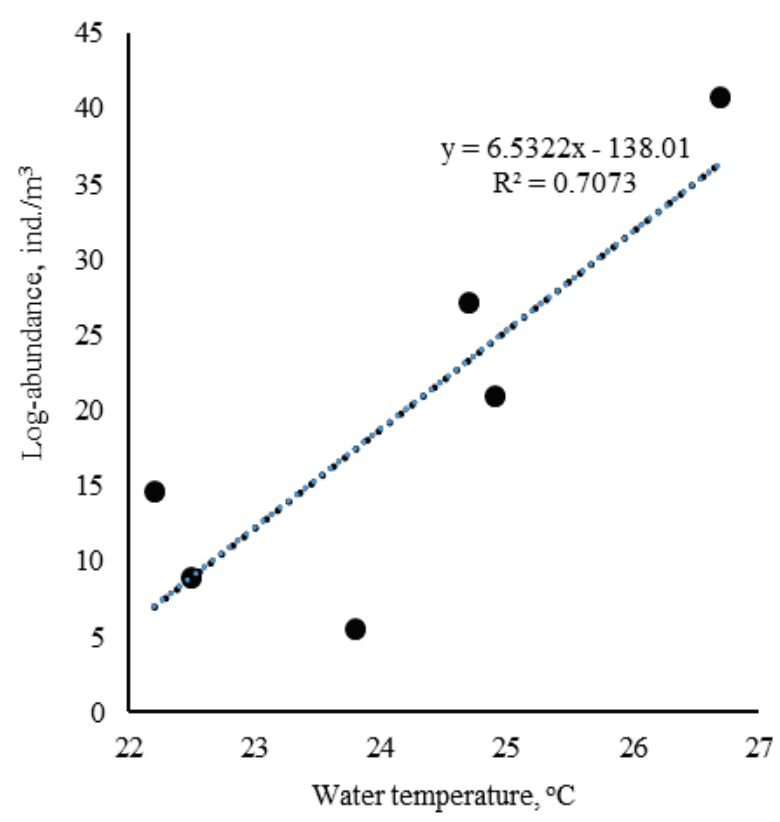

Fig. 3. Relationship between the abundance of cladocerans and water temperature in the Kremenchuk Reservoir in 2006, 2010-2013, 2020

Zooplankton species diversity varied in different years of the study. A total of 46 taxa were recorded in the reservoir during the study period, of which 33 were identified to the species level and 6 to the genus level. The number of taxa by years ranged 26 to 32 , and species from 17 to 27 (Table 1).

The most stable dominant group of zooplankton throughout all analyzed years were copepod nauplii (1.1-43.4\%) with abundances from $0.27 \cdot 10^{3}$ to $8.30 \cdot 10^{3}$ ind $/ \mathrm{m}^{3}$ and juvenile stages of Cyclopoida $(0.9$ $25.2 \%$ ) with abundances from $0.43 \cdot 10^{3}$ to $24.72 \cdot 10^{3} \mathrm{ind} . \mathrm{m}^{3}$. The other dominant species throughout the study period (except 2020) was Chydorus sphaericus $(6.2-64.0 \%)$ with abundances from $0.64 \cdot 10^{3}$ to $81.29 \cdot 10^{3}$ ind. $/ \mathrm{m}^{3}$. The following species were most frequently dominant, although periodically absent in the reservoir: Bosmina coregoni (1.2-23.8\%) with abundances of $0.30 \cdot 10^{3}$ to $18.18 \cdot 10^{3} \mathrm{ind} / \mathrm{m}^{3}$, Brachionus diversicornis (2$22 \%$ ) with abundances from $0.70 \cdot 10^{3}$ to $11.70 \cdot 10^{3} \mathrm{ind} . \mathrm{m}^{3}$, and Euchlanis dilatata $(1.0-13.8 \%)$ with abundances from $0.31 \cdot 10^{3}$ to $13.58 \cdot 10^{3} \mathrm{ind} . / \mathrm{m}^{3}$. Other zooplankton taxa were found in the reservoir periodically (Fig. 4). No significant relationship was detected between water temperature and abundances of most abundant zooplankton taxa except for Ch. sphaericus $(\mathrm{P}=0.034)$ and Ceriodaphnia sp. $(\mathrm{P}=0.050$, Fig. 5).

Three groups of zooplankters were detected based on their indicator weights in relation to water temperature: cryophiles included 5 species, thermophiles included only 2 species, and thermobionts included 10 species. The share of cryophiles in the total number (ind. $/ \mathrm{m}^{3}$ ) of zooplankters fluctuated within different ranges in some parts of the reservoir. For instance, it varied $0.0(2006,2011)$ to $36.9 \%(2012)$ in the upper part of the reservoir, $0.0 \%$ (2006) to $12.4 \%$ (2012) in the middle part, and $0.0 \%$ (2006) to $9.0 \%$ (2010) in the lower part. Thermophilic species also did not play a significant role in zooplankton abundance. Their share varied $0.0 \%(2006,2012)$ to $11.8 \%(2010)$ in the upper part, $0.0 \%(2012$, $2013)$ to $1.8 \%$ (2010) in the middle part, and $0.0 \%$ (2013) to $0.3 \%$ (2006) in the lower part. The largest share comprised thermobiont species, which accounted for $0.0 \%$ (2006) to $10.1 \%$ (2011) in the upper part, $9.6 \%(2013)$ to $25.7 \%$ (2020) in the middle part, $2.8 \%$ (2012) to $25.0 \%$ (2006) in the lower part. No statistically significant relationship was found between these parameters. To a large extent, this may be due to a strong effect of the hydrological regime of the Kremenchuk Reservoir, which, especially in the upper part, is characterized by significant inter-seasonal and interannual instability. At the same time, a certain tendency to a gradual increase in the abundance of thermobionts by years in the middle part of the reservoir was observed.

In general, significant fluctuations in the number of indicator species of pollution (3-16 species) were observed in different years and different parts of the reservoir as well as their abundances $\left(0.9 \cdot 10^{3}-130.4 \cdot 10^{3}\right.$ ind. $/ \mathrm{m}^{3}$ ) and saprobity (1.5-1.9), but there is a year-to-year tendency for an increase in the studied indicators in both inter-annual and spatial (from the upper to the lower parts of the reservoir) aspects (Fig. 6).

The largest number of indicator species was recorded for $\beta$-mesosaprobes (1-6) and oligo- $\beta$-saprobes (1-5), which allows us to identify water of the Kremenchuk Reservoir to the oligo- $\beta$-mesosaprobic zone. The least polluted water was in 2006-2012 in the upper part of the reservoir and its quality gradually significantly deteriorated from the upper to the lower part. Water of the middle part of the reservoir was most polluted in 2010, 2011 and 2020, when a very low number ( 2 species) of $\alpha$-mesosaprobes was recorded (Fig. 7). 
Table 1

Diversity and abundance $\left(10^{3} \mathrm{ind} . \mathrm{m}^{3}\right)$ of zooplankton taxa in the Kremenchuk Reservoir by years of the study

\begin{tabular}{|c|c|c|c|c|c|c|}
\hline Zooplankton taxa & 2006 & 2010 & 2011 & 2012 & 2013 & 2020 \\
\hline \multicolumn{7}{|l|}{ Rotifera } \\
\hline Keratella quadrata Müller, 1786 & - & - & - & - & - & $0.10 \pm 0.09$ \\
\hline K. cochlearis (Gosse, 1851$)$ & - & $1.06 \pm 0.85$ & $0.11 \pm 0.07$ & $0.12 \pm 0.12$ & $0.27 \pm 0.14$ & $1.79 \pm 0.84$ \\
\hline Brachionus forficula Wierzejski, 1891 & - & $1.05 \pm 0.92$ & - & - & - & - \\
\hline B. calyciflorus Pallas, 1766 & $0.69 \pm 038$ & $0.05 \pm 0.03$ & $0.35 \pm 0.18$ & $0.05 \pm 0.05$ & $0.22 \pm 0.11$ & $20.14 \pm 8.08$ \\
\hline B. diversicornis (Daday, 1883) & $5.85 \pm 1.86$ & $1.32 \pm 0.84$ & $3.34 \pm 1.73$ & $3,10 \pm 1,04$ & $0.59 \pm 0.20$ & $18.24 \pm 4.79$ \\
\hline B. plicatilis Müller, 1786 & $2.14 \pm 1.10$ & - & $0.02 \pm 0.02$ & $0.15 \pm 0.10$ & - & $24.08 \pm 8.78$ \\
\hline B. falcatus Zacharias, 1898 & - & - & - & - & $0.03 \pm 0.03$ & - \\
\hline B. quadridentatus Hermann, 1783 & $1.26 \pm 1.26$ & $0.93 \pm 0.85$ & $0.06 \pm 0.04$ & $0.11 \pm 0.07$ & $0.09 \pm 0.05$ & $0.73 \pm 0.64$ \\
\hline B. bennini Leissling, 1924 & - & - & - & $1.09 \pm 0.51$ & $3.80 \pm 2.46$ & - \\
\hline Synchaeta pectinata Ehrenberg, 1832 & - & - & - & $0.11 \pm 0.08$ & - & $0.40 \pm 0.35$ \\
\hline Gastropus hyptopus (Ehrenberg, 1838) & - & $0.02 \pm 0.02$ & $0.17 \pm 0.13$ & $0.39 \pm 0.24$ & $0.30 \pm 0.14$ & - \\
\hline Lecane luna (Müller, 1776) & - & - & $0.03 \pm 0.03$ & - & $0.48 \pm 0.35$ & - \\
\hline Polyarthra sp. & $0.15 \pm 0.10$ & $0.05 \pm 0.04$ & $0.67 \pm 0.27$ & $0.64 \pm 0.22$ & $0.86 \pm 0.36$ & $37.62 \pm 19.54$ \\
\hline Notholca sp. & $0.04 \pm 0.04$ & - & $0.04 \pm 0.04$ & - & - & - \\
\hline Ploesoma sp. & - & - & $\begin{array}{ll}-0.01 \\
-10\end{array}$ & $0.05 \pm 0.05$ & $0.03 \pm 0.03$ & - \\
\hline Trichocerca stylata (Gosse, 1851) & - & - & - & $\begin{array}{c}0.00+00 \\
-\end{array}$ & $\begin{array}{c}0.00+0.00 \\
-\end{array}$ & $3.09 \pm 0.84$ \\
\hline T. longiseta (Schrank, 1802) & - & - & - & - & - & $3.50 \pm 1.56$ \\
\hline Euchlanis dilatata Ehrenberg, 1832 & $0.65 \pm 0.39$ & $0.05 \pm 0.03$ & $0.73 \pm 0.19$ & $3.21 \pm 1.60$ & $0.33 \pm 0.22$ & $13.58 \pm 5.89$ \\
\hline Mytilina mucronata (Müller, 1773) & $0.52 \pm 0.31$ & $2.04 \pm 1.70$ & $0.07 \pm 0.07$ & & $0.06 \pm 0.05$ & - \\
\hline Filinia longiseta (Ehrenberg, 1834) & $0.35 \pm 0.28$ & $0.09 \pm 0.07$ & $1.81 \pm 0.78$ & $4.54 \pm 2.35$ & $1.60 \pm 0.61$ & $7.56 \pm 3.09$ \\
\hline F. terminalis (Plate, 1886) & - & - & - & - & - & $0.70 \pm 0.31$ \\
\hline Pompholyx complanata Gosse, 1851 & - & - & - & - & - & $16.89 \pm 6.21$ \\
\hline Bdelloidea Hudson, 1884 & - & - & - & - & - & $0.89 \pm 0.39$ \\
\hline $\begin{array}{l}\text { Asplanchna priodonta Gosse, } 1850 \\
\text { Cladocera }\end{array}$ & $1.32 \pm 0.51$ & $0.02 \pm 0.02$ & $0.39 \pm 0.19$ & $1.26 \pm 0.52$ & $0.05 \pm 0.04$ & $56.32 \pm 35.70$ \\
\hline Bosmina longirostris (Müller, 1785) & $8.85 \pm 5.11$ & $0.16 \pm 0.16$ & $0.89 \pm 0.32$ & $3.09 \pm 2.43$ & $0.41 \pm 0.19$ & $7.04 \pm 4.23$ \\
\hline B. coregoni Baird, 1857 & $3.21 \pm 1,33$ & $6.23 \pm 2.14$ & $1.03 \pm 036$ & $0.45 \pm 0.20$ & $1.77 \pm 0.44$ & $0.40 \pm 0.35$ \\
\hline Chydorus sphaericus (Müller, 1776) & $7.25 \pm 2.33$ & $11.36 \pm 2.95$ & $5.91 \pm 1.10$ & $35.72 \pm 14.59$ & $2.78 \pm 0.48$ & $0.30 \pm 0.26$ \\
\hline Daphnia longispina Müller, 1776 & - & $5.49 \pm 2.79$ & - & $0.05 \pm 0.05$ & $0.20 \pm 0.14$ & $0.90 \pm 0.66$ \\
\hline D. pulex Leydig, 1860 & - & - & $0.15 \pm 0.09$ & - & - & $0.25 \pm 0.11$ \\
\hline D. cucullata Sars, 1862 & $0.024 \pm 0.024$ & $2.41 \pm 1.30$ & $0.04 \pm 0.04$ & - & $0.06 \pm 0.04$ & - \\
\hline Ceriodaphnia sp. & $0.38 \pm 0.27$ & $0.76 \pm 0.17$ & $0.21 \pm 0.11$ & $0.68 \pm 0.19$ & $0.13 \pm 0.06$ & $0.10 \pm 0.09$ \\
\hline Moina sp. & - & $0.12 \pm 0.05$ & - & - & - & - \\
\hline Alona spp. & $0.18 \pm 0.13$ & - & - & - & - & - \\
\hline Pleuroxus uncinatus (Baird, 1850) & - & & $0.02 \pm 0.02$ & - & $0.02 \pm 0.02$ & - \\
\hline Picripleuroxus striatus (Schödler, 1863) & - & $0.16 \pm 0.09$ & & - & $0.03 \pm 0.03$ & - \\
\hline Cladocera sp.,juv. & $0.32 \pm 0.25$ & $0.20 \pm 0.20$ & $0.04 \pm 0.03$ & $0.05 \pm 0.05$ & $0.14 \pm 0.07$ & $2.80 \pm 2.43$ \\
\hline Diaphanosoma brachyurum (Liévin, 1848) & $0.35 \pm 0.27$ & $0.24 \pm 0.13$ & $0.06 \pm 0.04$ & $0.33 \pm 0.09$ & - & - \\
\hline Cornigerius maeoticus (Pengo, 1879) & $0.18 \pm 0.13$ & - & $0.17 \pm 0.13$ & $0.37 \pm 0.26$ & - & $0.60 \pm 0.30$ \\
\hline Leptodora kindtii (Focke, 1844) & $0.17 \pm 0.07$ & $0.05 \pm 0.05$ & $0.33 \pm 0.09$ & - & - & $0.20 \pm 0.17$ \\
\hline $\begin{array}{l}\text { Podonevadne trigona (Sars, 1897) } \\
\text { Copepoda }\end{array}$ & - & - & - & - & - & $2.00 \pm 1.25$ \\
\hline Copepoda nauplii & $4.49 \pm 1.75$ & $2.87 \pm 1.34$ & $6.56 \pm 0.98$ & $7.43 \pm 0.80$ & $3.45 \pm 0.78$ & $13.24 \pm 1.92$ \\
\hline Copepodini & $9.23 \pm 3.36$ & $2.61 \pm 0.53$ & $2.66 \pm 0.48$ & $5.23 \pm 1.69$ & $4.44 \pm 1.34$ & $3.51 \pm 0.72$ \\
\hline Diaptomus sp. & - & $0.02 \pm 0.02$ & $1.74 \pm 0.50$ & $1.15 \pm 0.43$ & $0.43 \pm 0.26$ & $3.35 \pm 2.59$ \\
\hline Cyclops sp. & $1.57 \pm 0.54$ & $2.33 \pm 0.34$ & $0.61 \pm 0.21$ & $1.23 \pm 0.43$ & $0.45 \pm 0.28$ & $0.80 \pm 0.46$ \\
\hline $\begin{array}{l}\text { Cyclopoida juveniles } \\
\text { Bivalvia }\end{array}$ & $0.78 \pm 0.70$ & & $1.24 \pm 0.99$ & $1.20 \pm 0.74$ & $0.34 \pm 0.15$ & $1.55 \pm 0.42$ \\
\hline Dreissena sp. veligers & - & - & - & $0.26 \pm 0.20$ & - & $13.01 \pm 3.16$ \\
\hline Total: & $49.95 \pm 15.41$ & $41.69 \pm 9.37$ & $29.45 \pm 4.25$ & $72.06 \pm 17.60$ & $23.40 \pm 3.79$ & $255.68 \pm 79.60$ \\
\hline
\end{tabular}

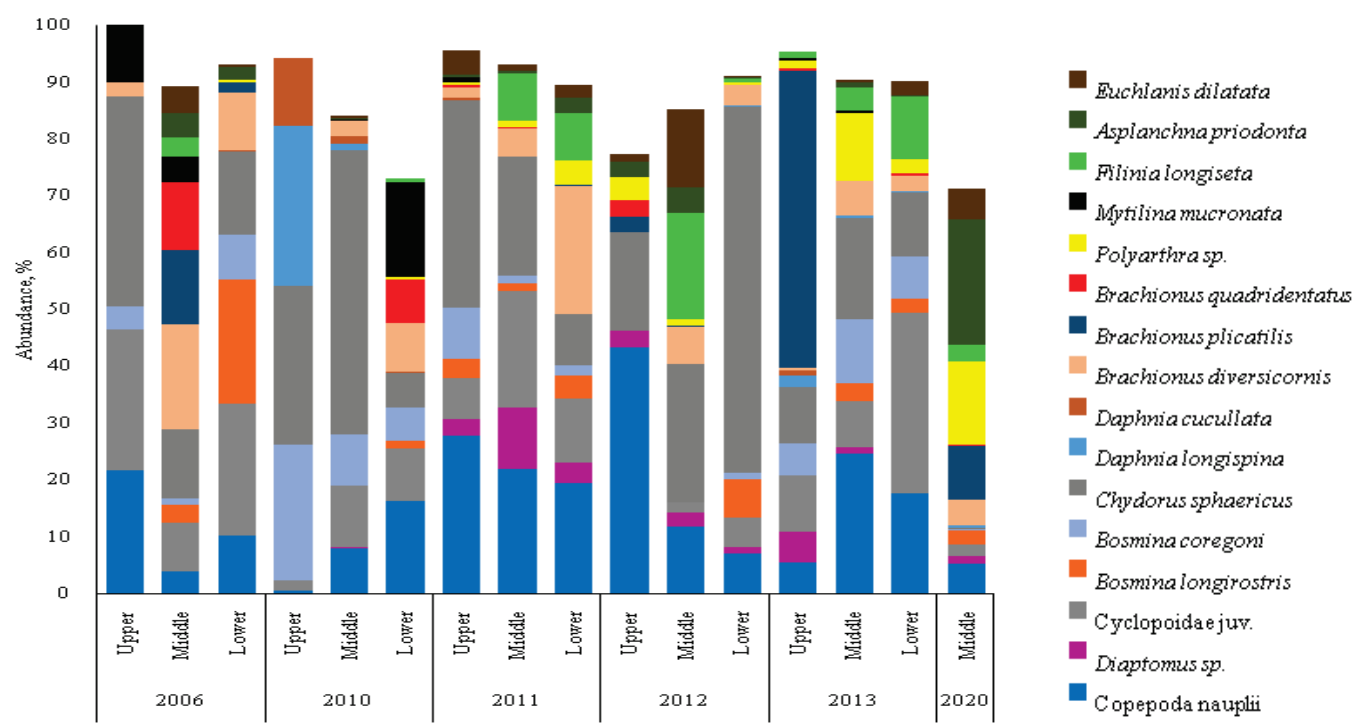

Fig. 4. Abundances of dominating zooplankton taxa in different parts of the Kremenchuk Reservoir by years (\%): upper, middle, lower are parts of the reservoirs (see Materials and methods) 

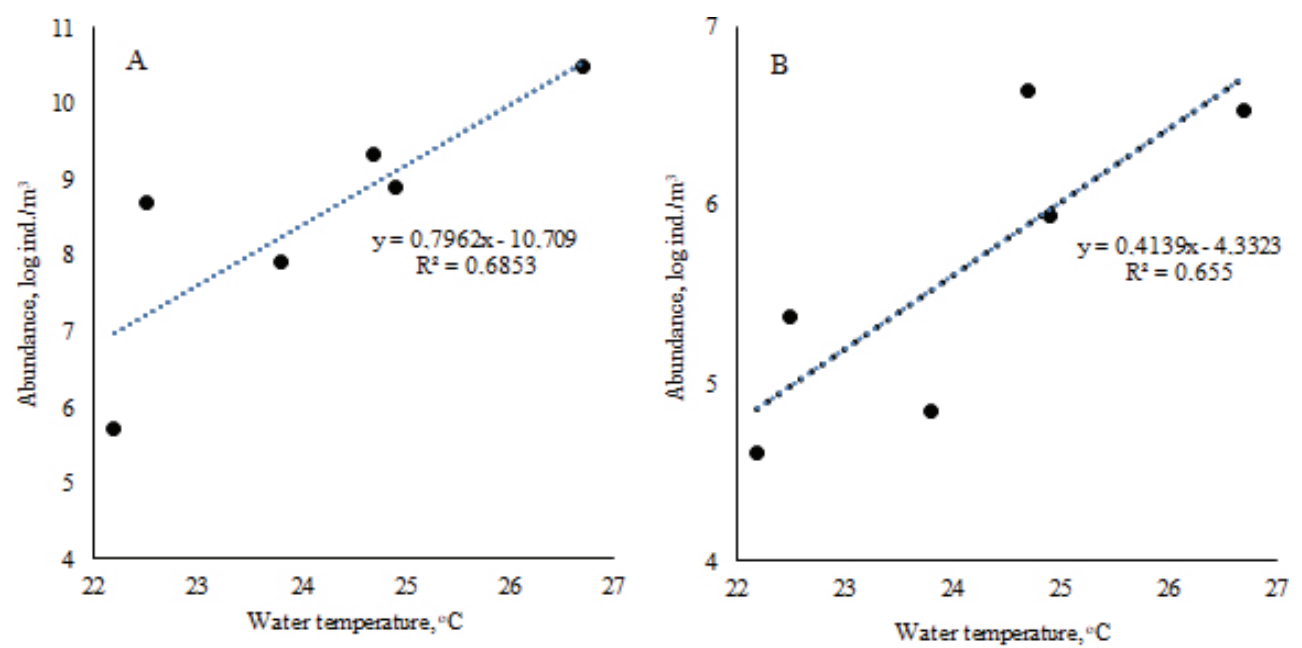

Fig. 5. Relationship between water temperature and abundances of Chydorus sphaericus (a) and Ceriodaphnia sp. (b) in the Kremenchuk Reservoir in 2006, 2010-2013, 2020

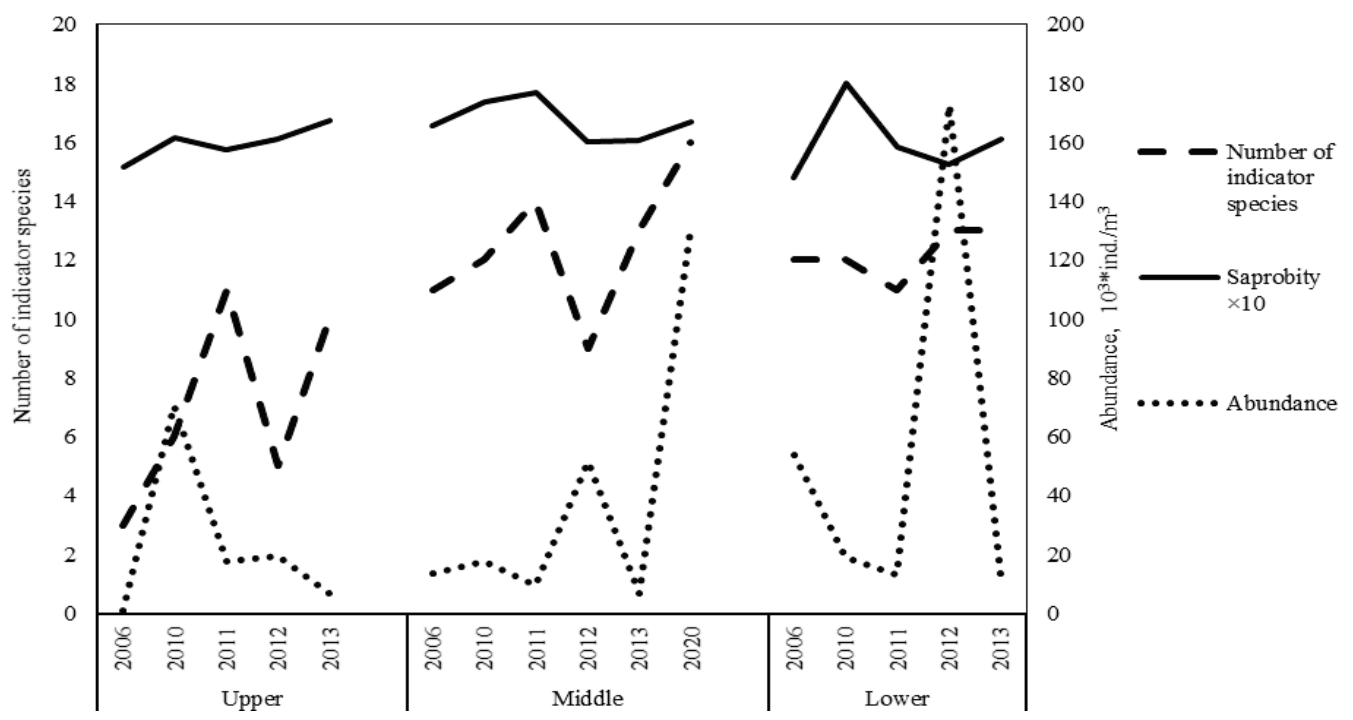

Fig. 6. Year-to-year dynamics of water pollution parameters in different parts of the Kremenchuk Reservoir

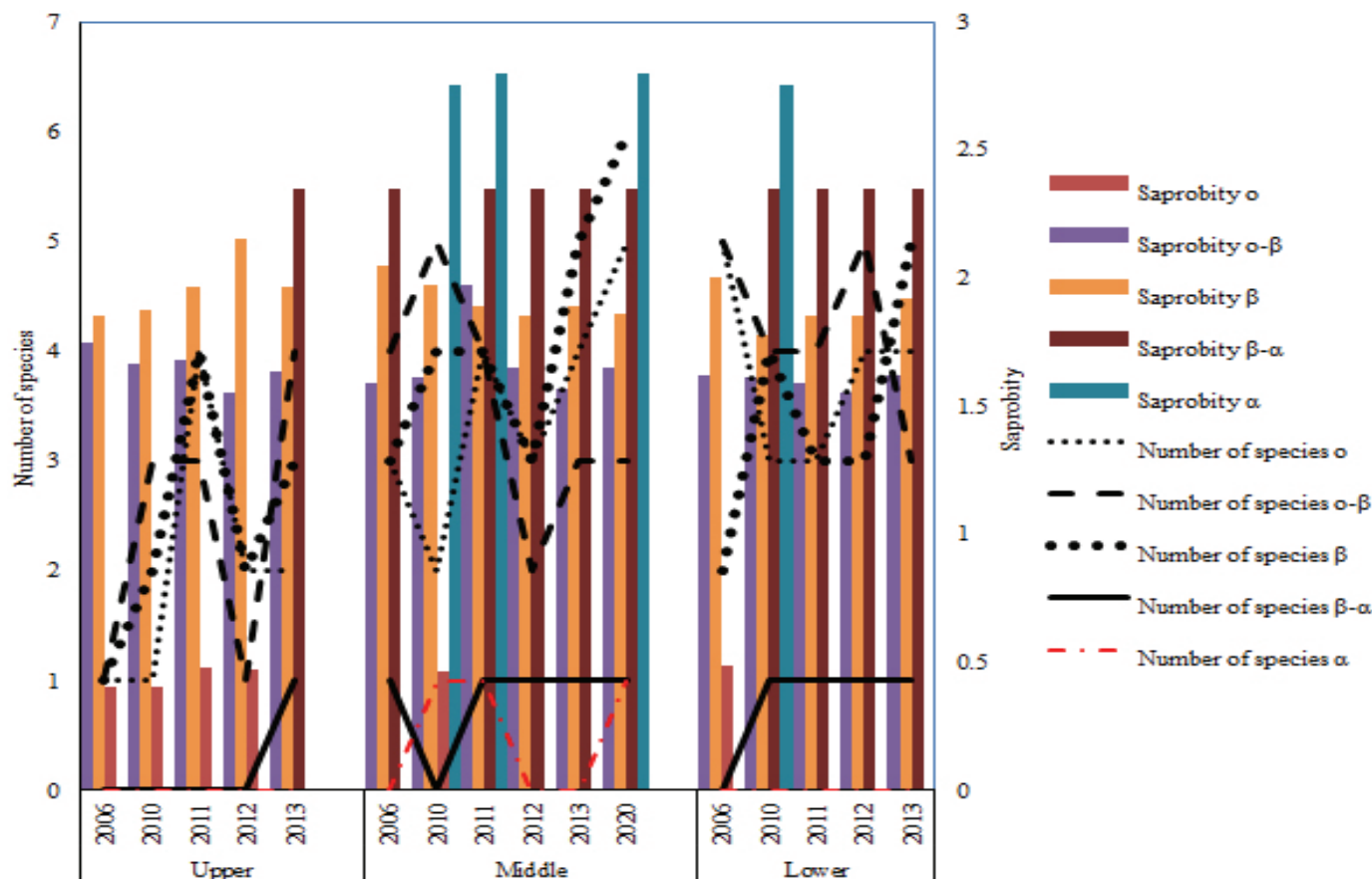

Fig. 7. Water pollution by saprobity degree and dynamics of changes of the number of indicator species in different parts of the Kremenchuk Reservoir by years 


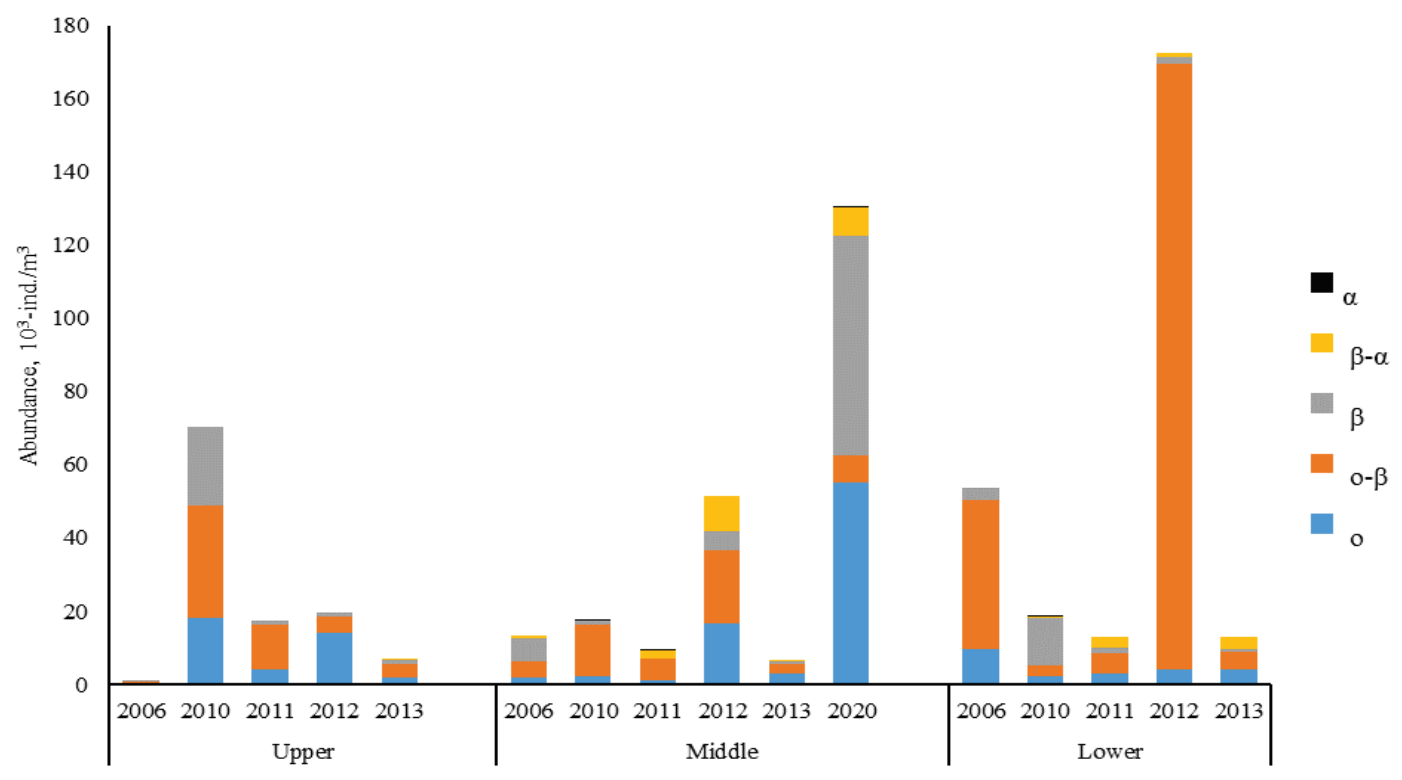

Fig. 8. Abundances of indicator species of pollution in different parts of the Kremenchuk Reservoir by years

The abundance of each of indicator species fluctuated very significantly over the years in different parts of the reservoir. The most abundant were zooplankters belonging to o-, o- $\beta-$, and $\beta$-saprobes. Abundances in 2020 in the middle part of the reservoir and those of 2012 in the lower part of the reservoir differed most significantly from the others. In 2020, water was quite clean and most abundant in zooplankton samples were o- and $\beta$-saprobic organisms, accounting for $42 \%$ and $46 \%$, respectively. In 2012, in the lower reaches of the reservoir, $96 \%$ of indicator species belonged to o- $\beta$-saprobes. On average, water of the Kremenchuk Reservoir can be classified as $\beta$-saprobic, which to some extent forms the species composition of zooplankton of the reservoir and its dominant complexes (Fig. 8).

\section{Discussion}

Significant inter-annual fluctuations in the abundances of zooplankton of the Kremenchuk Reservoir were observed, but without clear trends. A similar phenomenon was recorded in previous years, in particular during the period of 2001-2004, when zooplankton biomass in this reservoir ranged 0.06 to $1.68 \mathrm{~g} / \mathrm{m}^{3}$ (Kruzhylina, 2005).

Among the investigated individual groups of zooplankters, some significant trends were observed only for cladocerans. The absence of trends in the abundances of copepods and rotifers might be due to the fact that copepods are considered to prefer cold water (Rogozin et al., 2015; Verbitsky et al., 2017) and the water temperature during the study was unfavourable for their development, while rotifers are considered to be eurythermal (Rogozin et al., 2015) and can easily tolerate significant temperature differences. In addition, copepods usually have a lower abundance in the environment in summer compared to spring or autumn due to a combination of predation and diapauses that they enter to avoid mid-summer predation (George, 1973). No significant relationships between warming and rotifer biomass was observed in other studies, e.g. in Lake Võrtsjärv in Estonia (Agasild et al., 2007; Cremona et al., 2020). Inter-annual variations in rotifer biomasses are considered to be affected by rather interspecific and trophic relationships than by temperature (Agasild et al., 2007).

The reasons for changes in the dominant groups of zooplankton in different years may be due to a number of factors of both anthropogenic and natural origin. The most important of these may be factors such as the temperature of the aquatic environment and pollution by discharges from industry and agricultural lands (Frolova et al., 2013; Fetter \& Yermolaeva, 2018).

The taxonomic composition of zooplankton was typical for the Kremenchuk Reservoir, having been established there after the end of the period of transformation of lotic environments to lentic habitats. The dominant zooplankton complex was composed of such species as Ch. sphaericus, Bosmina coregoni, B. diversicornis, E. dilatata, which was consistent with the results of previous studies in both Kremenchuk and other Dnipro reservoirs for the beginning of 2000s (Kruzhylina, 2005). Dreissena sp. veligers in zooplankton samples were recorded only in 2020. Given the rather high biomasses of Dreissena sp. in the Kremenchuk Reservoir, which accounted for more than $50 \%$ of the total biomass of mollusks (Kruzhylina, 2015), this may be due to the seasonal nature of the dynamics of the abundance of this species, which can be specific for different water bodies. We should note a significant (9.4-30.8 times) increase in the number of rotifers in the samples in 2020, which is consistent with the data of other authors, which showed a significant role of Dreissena sp. veligers in the diet of such rotifers as Asplanchna sp. (Lazareva et al., 2015). Accordingly, the change in the dominant groups from cladocerans to rotifers in 2020 against the background of the abovementioned increase in their abundance and, especially, biomass (19.0-93.3 times) may be associated with a particular year and have no stable trend.

In general, the dynamics of zooplankton taxa composition in the context of processes of ecological succession indicate a transition to a long phase of functioning, in which the structure of zooplankton communities remains relatively stable, although with some changes in absolute and relative quantitative indicators of the development of individual taxa. Production indicators such as abundance and biomass of zooplankton remain at a high enough level for reservoirs of this type (Pashkova, 2014; Trokhymets, 2014).

Thus, the analysis of the state and dynamics of zooplankton communities of the Kremenchuk Reservoir during the studies period does not allow us to consider the water temperature as a factor significantly affectting species composition or their abundances except some individual species (e.g., Ch. sphaericus). Ch. sphaericus is a typical small-sized cladoceran, which is common in eutrophic water bodies with abundant detritus and high cyanobacterial concentrations and some studies showed an increase in its abundance with increasing chlorophyll concentration in some years; however, these relationships were not seen in other years (Vijverberg \& Boersma, 1997). The authors suggested that the observed trends were caused by a food effect, and partially by predation pressure. Zooplankton is known to respond to changes in the trophic state of a water body, while the climate warming causes general eutrophication, which in turn can affect zooplankters (Jeppesen et al., 2002; Carvalho et al., 2012). Therefore, the relationship between the abundance of cladocerans and $C h$. sphaericus, in particular, and water temperature, which was observed during the study period, was probably due to temperature-related changes in the trophic state of the Kremenchuk Reservoir in different years.

Taking into account that the Kremenchuk Reservoir receives polluted and conditionally pure water of industrial and domestic effluents, a significant part of which containing organic matter (Vyshnevsky, 2011), this segment of external influence needs a separate assessment in terms of changes in zooplankton communities. For this purpose, the level of pollution of the reservoir was assessed using zooplankton indicators of water 
saprobity. According to ecological criteria, the entire studied water area of the reservoir was characterized by generally unbalanced (or weakened) potential of zooplankton communities for water self-purification. The largest number of indicator species was recorded among zooplankters belonging to $\beta(1-6)$ and o- $\beta$ saprobes (1-5). Parameters of water pollution in different years and in different parts of the reservoir differed significantly, which might depend on the presence or absence (in a certain period of time) of polluting discharges. The total saprobity index in different years ranged 1.5 to 1.9 and its changes have a multi-vector nature depending on the hydrological and temperature regimes that may be associated with the intensity of anthropogenic load in some parts of the reservoir (Bukovsky \& Kolomeytseva, 2013).

Significant fluctuations in water pollution in different years and in different parts of the reservoir can to some extent be explained by the presence or absence (in a certain period of time) of polluting effluents. Water pollution to some extent affects the species composition of zooplankton in the reservoir. As water pollution increases, such o-saprobic species as B. coregoni, Synchaeta pectinata, E. dilatata, Gastropus hyptopus, Polyarthra sp., Trichocerca stylata can disappear and be replaced by $\beta$ - and $o-\beta$-saprobic species. The largest number of indicator species recorded in the reservoir during the study period belonged to $\beta$ - and o- $\beta$-saprobes. The $\beta$-saprobes included Daphnia longispina, Asplanchna priodonta, while the o- $\beta$-saprobes included B. longirostris, $C$. sphaericus, Daphnia cucullata, Pleuroxus uncinatus, $P$. striatus. The $\alpha$-saprobic species that were found in small numbers in the reservoir included such species as Daphnia pulex and Moina sp.

Despite the fact that there are certain tendencies for an increase or decrease of certain species of zooplankton depending on change in environmental parameters in the reservoir, no other mathematically significant relationships were detected. This is quite clear, because in addition to temperature, the abundance of zooplankters in the reservoir may be significantly affected by a number of other factors such as hydrological regime, weather conditions (wind, sunlight), chemical composition of water, various pollutants (industrial wastewater, agricultural lands, $\mathrm{pH}$ (de Eyto \& Irvine, 2001; Frolova et al., 2013; Yermolaeva et al., 2016; Fetter \& Yermolaeva, 2018). In general, global warming is unlikely to supplant the effects of changing nutrient loading and fish predation, which are considered to be the major drivers of zooplankter dynamics (McKee et al., 2002).

Moreover, significant factors affecting the level of zooplankton development are presence of zooplankton-eating fish in water bodies (Kruzhylina, 2009; Golubkov, 2013; Golubkov et al., 2018), as well as the qualitative and quantitative composition of phytoplankton. For instance, the biomass of non-predatory cladocerans significantly depends on the combination of biomass of cyanobacteria with cell volumes of $50-100 \mu \mathrm{m}^{3}$ and chlorococcal algae with cell volumes of $100-150 \mu \mathrm{m}^{3}$. The insignificant level of vegetation mainly of small cyanobacteria and chlorococcal algae causes low quantitative and qualitative development of zooplankton in the Kremenchuk Reservoir (Kruzhylina \& Didenko, 2007). Therefore, it can be difficult to trace a clear reliable relationship between zooplankton and one environmental factor such as temperature in natural conditions. Therefore, quantitative assessment of the impact of climate change on zooplankton of the Kremenchuk as well as other Dnipro reservoirs is currently impossible, making it necessary to conduct further studies to differentiate the impact of certain external factors on the structural and functional characteristics of zooplankton and assess consequences of these changes on other aquatic organisms including fish.

\section{Conclusion}

According to results of the studies of 2006-2020, 26 to 32 taxa were observed in the zooplankton of the Kremenchuk Reservoir, where the dominant groups were cladocerans and rotifers. Zooplankton abundance in the reservoir during the study period ranged $23 \cdot 10^{3}$ to $256 \cdot 10^{3} \mathrm{ind} . / \mathrm{m}^{3}$, and biomass 0.14 to $0.89 \mathrm{~g} / \mathrm{m}^{3}$. A significant positive relationship was observed between the abundance of cladocerans, including some individual species such as Ch. sphaericus and water temperature.

It was not possible to trace clear reliable patterns in relationships between water temperature and zooplankton abundance. This can be explained by the fact that its abundance is also significantly affected by a num- ber of other factors such as hydrological regime, weather conditions (wind, solar radiation), $\mathrm{pH}$ of the aquatic environment, which are constantly changing. In addition, significant factors affecting the level of zooplankton development are the presence of zooplankton-eating fish in the water body and the qualitative and quantitative composition of phytoplankton. It is probably too early to assess the impact of the climate change on zooplankton as these changes are still unstable and short in time, but it is necessary to constantly monitor the biota of aquatic ecosystems to further study and summarize the data, which could later allow identifying such changes.

\section{References}

Agasild, H., Zingel, P., Tõnno, I., Haberman, J., \& Nõges, T. (2007). Contribution of different zooplankton groups in grazing on phytoplankton in shallow eutrophic Lake Võrtsjärv (Estonia). Hydrobiologia, 584, 167-177.

Bukovsky, M. E., \& Kolomeytseva, N. N. (2013). Saprobnost' rek na uchastkah s razlichoj antropogennoj nagruzkoj $v$ gody raznoj vodnosti [River saprobity on sites with various anthropogenic pressures in years with various water availabilities]. Povolzhskiy Journal of Ecology, 4, 368-373 (in Russian).

Carter, J. L., \& Schindler, D. E. (2012). Responses of zooplankton populations to four decades of climate warming in lakes of Southwestern Alaska. Ecosystems, $15,1010-1026$.

Carvalho, L., Miller, C., Spears, B. M., Gunn, I. D. M., Bennion, H., Kirika, A., \& May, L. (2012). Water quality of Loch Leven: Responses to enrichment, restoration and climate change. Hydrobiologia, 681, 35- 47.

Cremona, F., Agasild, H., Haberman, J., Zingel, P., Nõges, P., Nõges, T., \& Laas, A. (2020). How warming and other stressors affect zooplankton abundance, biomass and community composition in shallow eutrophic lakes. Climatic Change, $159,565-580$.

de Eyto, E., \& Irvine, K. (2001). The response of three chydorid species to temperature, $\mathrm{pH}$ and food. Hydrobiologia, 459, 165-172.

Fetter, G. V., \& Yermolaeva, N. I. (2018). Vliyanie abioticheskih faktorov na strukturu zooplanktona malyh ozer yuga Zapadnoj Sibiri [The influence of abiotic factors on zooplankton structure in small lakes in the south of West Siberia]. Bulletin of the Altay Branch of the Russian Geographical Society, 49(2), 95-103 (in Russian).

Fomina, Y. Y., \& Syarki, M. T. (2018). Sovremennoe sostoyanie zooplanktona Petrozavodskoj guby Onezhskogo ozera i ego otklik na izmenenie klimata [Modern state of zooplankton and its response to climate change in Petrozavodsk bay of the Lake Onega]. Transactions of the Karelian research centre of the Russian Academy of Sciences, 9, 54-64 (in Russian).

Frolova, L. A., Nazarova, L. B., Pestryakova, L. A., \& Herzschuh, U. (2013). Analysis of the effects of climate-dependent factors on the formation of zooplankton communities that inhabit arctic lakes in the Anabar River Basin. Contemporary Problems of Ecology, 6, 1-11.

George, D. G. (1973). Diapause in Cyclops vicinus. Oikos, 24, 136-142.

Golubkov, S. M. (2013). Rol' konsumentov v dinamike pishchevyh tsepej i funktsionirovanii vodnyh ekosistem [Role of consumers in the dynamics of food webs and functioning of water ecosystems]. Journal of Siberian Federal University, Biology, 4(6), 335-353 (in Russian).

Golubkov, S. M., Shadrin, N. V., Golubkov, M. S., Balushkina, E. V., \& Litvinchuk, L. F. (2018). Food chains and their dynamics in ecosystems of shallow lakes with different water salinities. Russian Journal of Ecology, 5, 391-398.

Gubachek, Z. (ed.). (1977). Unifitsirovannye metody issledovaniya kachetsva vod. Metody biologicheskogo analiza vod. Prilozhenie 2. Atlas saprobnyh organizmov [Unified methods of the study of water quality. Methods of biological analysis of water. Annex 2. Atlas of saprobic organisms]. Sovet Ekonomicheskoj Vzaimopomoshchi, Moscow (in Russian).

Jeppesen, E., Jensen, J. P., \& Søndergaard, M. (2002). Response of phytoplankton, zooplankton, and fish to reoligotrophication: an 11 year study of 23 Danish lakes. Aquatic Ecosystem Health and Management, 5, 31-43.

Jeziorski, A., Keller, B., Dyer, R., Paterson, A, \& Smol, J. (2016). Differences among modern-day and historical cladoceran communities from the "Ring of Fire" lake region of northem Ontario: Identifying responses to climate warming. Fundamental and Applied Limnology, 186/3, 203-216.

Korneva, L. G., Lazareva, V. I., Mineeva, N. M., Sigareva, L. E., Sokolova, E. A., Timofeeva, N. A., Mitropol'skya, I. V., \& Solovyeva, V. V. (2019). The state and dynamics of biological communities in the Rybinsk Reservoir under climate changes. Joumal of Siberian Federal University, Biology, 12(2), 160-179.

Kruzhylina, S. V. (2005). Stan ta dynamika kormovoji bazy ryb-zooplanktonofagiv Kremenchyts'kogo vodoskhovyshcha [State and dynamics of food supply of zooplanktivorous fishes of the Kremenchuk Reservoir]. In: Kachnoi, A. S. (Ed.). Problemy vosproizvodstva aborigennyh vidov ryb [Problems of the propagation of aboriginal fish species]. Svit Rybalki, Kyiv. Pp. 101-105 (in Ukrainian).

Kruzhylina, S. V. (2009). Zhyvlennya ta trofichni vzaiemovidnosyny molodi osnovnyh promyslovyh vydiv ryb Kremenchuts'kogo vodoskhovyshcha [Feeding 
and trophic relationships of juveniles of major commercial fish species of the Kremenchuk Reservoir]. Hydrobiological Joumal, 45(6), 25-35 (in Ukrainian).

Kruzhylina, S. V. (2015). Riven' rozvytku hidrobiontiv yak kharakterystyka umov nagulu ryb vodoskhovyshch dniprovs'kogo kaskadu [The level of hydrobiont development as a characteristic of the conditions of fish fattening in the Dnieper reservoirs]. Fisheries Science of Ukraine, 4, 15-30 (in Ukrainian)

Kruzhylina, S. V., \& Didenko, O. V. (2007). Stukturno-funktsional'nye harakteristiki zooplanktona Kremenchygs'kogo vodoskhovyshcha v suchasnyi period ta iogo vzaiemozv'azok z deyakymy komponentamy fitoplanktona [Structural and functional characteristics of zooplankton of the Kremenchuk Reservoir in the current period and their relationships with some components of phytoplankton]. Fisheries Science of Ukraine, 2, 71-76 (in Ukrainian).

Lazareva, V. I., Kopylov, A. I., Sokolova, E. A., \& Pryanichnikova, E. G. (2015) Veligery dreissenid (Bivalvia, Dreissenidae) v trofichrskoi seti planktona Rybinskogo vodokhranilishcha [Veliger larvae of Dreissena (Bivalvia, Dreissenidae) in the plankton foodweb of the Rybinsk Reservoir]. Povolzhskiy Journal of Ecology, 1, 42-45 (in Russian)

McCauley, E. (1984). The estimation of the abundance and biomass of zooplankton in samples. In: Downing, J. A., \& Rigler, F. H. (Eds.). A manual for the assessment of secondary productivity in fresh waters. Blackwell Scientific Publishers, Boston. Pp. 228-265.

McKee, D., Atkinson, A., Collings, S., Eaton, J., Harvey, I., Heyes, T., Hatton, K., Wilson, D., \& Moss, B. (2002). Macro-zooplankter responses to simulated climate warming in experimental freshwater microcosms. Freshwater Biology, 47, $1557-1570$.

Mordukhai-Boltovskoi, F. D. (1954). Materialy po srednemu vesy vodnyh bespozvonochnyh basseina Dona [Materials on the average weight of aquatic invertebrates of the Don River basin]. In: Problems of Hydrobiology of Inland Waters. Zoological Institute of the Academy of Sciences of USSR, Leningrad. Pp. 223 241 (in Russian).

Pashkova, O. V. (2003). Etapy i osobennosti mnogoletney suktsessii zooplanktona pelagiali Kanevskogo vodohranilishcha [Stages and features of multiannual succession of pelagic zooplankton in the Kanev Reservoir]. Hydrobiological Journal, 39(6), 42-56 (in Russian).

Pashkova, O. V. (2010). Litoral'nyi zooplankton u Dniprovs'kyh vodoskhovyshchah [Littoral zooplankton in Dnieper reservoirs of different types]. Scientific Issues of Ternopil Volodymyr Hnatiuk National Pedagogical University, 43, 395-398 (in Ukrainian).

Pashkova, O. V. (2014). Mechanisms and peculiarities of the functioning of pelagic zooplankton of the Dnieper reservoirs (on the example of the upper section of the Kanev Reservoir). Hydrobiological Journal, 50(1), 30-47.

Rogozin, A. G., Snit'ko, L. V., \& Timoshkin, O. A. (2015). Thermoindicator properties of zooplankton species and their measurements. Water Resources, 42(1), 91-97.

Romanenko, V. D., Yakushin, V. M., Shcherbak, V. I., TImchenko, V. M., Pligin, Y. V., Pashkova, O. V., Tsaplina, K. M., Semeniuk, N. Y., Maistrova, N. V., Golovko, T. V., Zadorozhna, G. M., Vandiuk, N. S., Linchuk, M. I., Kalinichenko, K. P., Matchinskaya, S. F., \& Zhelezniak, N. I. (2019). Bioriznomanittia ta bioresursnyi potentsial ekosistem dniprovs'kyh vodoskhovyshch v umovah klimatychnyh zmin i rozvytku biologichnoi invazii [Biodiversity and bioresource potential of ecosystems of the Dnieper reservoirs in conditions of clima- tic changes and development of biological invasions]. Naukova Dumka, Kyiv (in Ukrainian)

Shcherbak, V. I., \& Yemel'yanov, L. V. (2002). Bioraznoobraziye i strukturno-funktional'naya organizatsiya nekotoryh komponentov bioty Zaporozhskogo i Kahovskogo vodohranilishch $\mathrm{v}$ usloviyah antropogennogo pressa [Biodiversity and structural-functional organization of some components of biota of Zaporozhske and Kakhovske reservoirs in conditions of anthropogenic stress]. Hydrobiological Journal, 38(5), 17-25 (in Russian).

Shcherbak, V. I., Andreev, A. D., \& Hoshovskaya, G. A. (1991). Otsenka vliyania uvelicheniya srabotki urovnei dneprovskih vodohranilishch na ih bioproduktivnost' i kachestvo vody [Assessment of the impact of an increase in the drawdown of the levels of the Dnieper reservoirs on their bioproductivity and water quality]. Gidrotekhnicheskoe Stroitel'stvo, 2, 51-53 (in Russian).

Sládeček, V. (1985). Scale of saprobity. SIL Proceedings, 22(4), 2337-2341.

Sokolov, L. V. (2010). Klimat v zhizni rasteniy i zhivotnyh [Climate in the life of plants and animals]. Tessa, Saint Petersburg (in Russian).

Trokhymets, V. N. (2014). Littoral zooplankton of the downstream area of Kaniv Reservoir. Inland Water Biology, 7, 154-160.

Vadadi-Fulop, C., Sipkay, C., Meszaros, G., \& Hufnagel, L. (2012). Climate change and freshwater zooplankton: What does it boil down to? Aquatic Ecology, 46, 501-519.

Verbitsky, V. B., Kurbatova, S. A., \& Verbitskaya, T. I. (2017). Reaktsii zooplanktona na temperaturnyie vozdeiztviya. I. Dinamika chislennosti populyatsiy Cladocera pri neperiodicheskih izmenenieah temperatury [Reactions of zooplankton on temperature effects. I. Influence of the nonperiodic temperature changes on the population dynamics of Cladocera]. Transactions of Papanin Institute for Biology of Inland Waters Russian Academy of Sciences, 78, 14-36 (in Russian).

Vijverberg, J., \& Boersma, M. (1997). Long-term dynamics of small-bodied and large-bodied cladocerans during the eutrophication of a shallow reservoir, with special attention for Chydorus sphaericus. Hydrobiologia, 360, 233-242.

Vyshnevsky, V. I. (2011). Rika Dnipro [Dnieper River]. Interpress LTD, Kyiv (in Ukrainian).

Watkins, J., Rudstam, L., \& Holeck, K. (2011). Length-weight regressions for zooplankton biomass calculations - A review and a suggestion for standard equations. Cornell Biological Field Station Publications and Reports, Bridgeport.

Yermolaeva, N. I. (2008). Vodnye ekosistemy. Osobennosti formirovaniya zooplankotna vodohranilishch: analiticheskiy obzor [Water ecosystems. Peculiarities of zooplankton formation in reservoirs: analytical review]. GPNVB SO RAN, Novosibirsk (in Russian).

Yermolaeva, N. I., Zarubina, E. Y., \& Dvurechenskaya, S. Y. (2016). Sutochnaya dinamika gidrohimicheskih pokazatelei i zooplanktona v litorali Novosibirskogo vodohranilishcha [Diel dynamics of hydrochemical characteristics and zooplankton in the littoral of the Novosibirsk reservoir]. Povolzhskiy Journal of Ecology, 2, 155-166 (in Russian).

Zimbalevskaya, L. N. (1989). Litoral'nyi zooplankton [Littoral zooplankton]. In: Shcherbak, G. I. (Ed.). Invertebrates and fishes of the Dnieper and its reservoir. Naukova Dumka, Kiev. Pp. 5-21 (in Russian).

Zimbalevskaya, L. N., Pligin, Y. V., \& Khoroshikh, L. A. (1987). Struktura i suktsesii litoral'nyh biotsenozov [Structure and successions of littoral biocenoses of the Dnieper reservoirs]. Naukova Dumka, Kiev (in Russian). 